\title{
IAMJ
}

INTERNATIONAL

AYURVEDIC

MEDICAL JOURNAL

[d] (1)

Review Article

ISSN: 2320-5091

Impact Factor: 6.719

\section{PRE-EMPTIVE REGULATIONS OF COVID-19 DURING PREGNANCY - AN AYURVEDIC VIEW}

\author{
Nikitha Sirigere ${ }^{1}$, Noor Fathima ${ }^{2}$, Laxmi Kirana $\mathbf{P}^{3}$ \\ ${ }^{1}$ Associate Professor, Dept. of Prasuti Tantra \& Stree Roga, Govt. Ayurveda Medical College and Hospital, \\ Bengaluru- 560009, Karnataka, India \\ ${ }^{2}$ Assistant Professor, Dept. of Prasuti Tantra \& Stree Roga, Govt. Ayurveda Medical College and Hospital, \\ Bengaluru- 560009, Karnataka, India \\ ${ }^{3}$ Internee, Dept. of Prasuti Tantra \& Stree Roga, Govt. Ayurveda Medical College and Hospital, Bengaluru- 560009, \\ Karnataka, India
}

Corresponding Author: drnikithamahesh@gmail.com

\section{https://doi.org/10.46607/iamj1809032021}

(Published online: March 2021)

Open Access

(C) International Ayurvedic Medical Journal, India 2021

Article Received: 19/02/2021 - Peer Reviewed: 26/02/2021 - Accepted for Publication: 05/03/2021

Check for updates

\section{ABSTRACT}

Pregnancy is a phenomenal and remarkable time in any woman's life which requires added care and attention. Pregnancy is a sensitive state where the woman is more susceptible for infections. Amidst the Global Pandemic of Covid-19 special awareness and protection is of considerable necessity. In this view, Ayurveda being the Traditional Indian Medicine plays a crucial role in safeguarding the mother along with the growing fetus. Classical reference gives emphasis to the use of herbal drugs (Garbhasthapaka dravyas) which possess Anti-oxidant and Immunomodulator properties. Ayurveda also provides the evidence of Ahara, Vihara, Aushada \& Sadvritta which is imperative in every pregnant women. In this phase, as the body demands extra nutrition for the developing fetus the periodic dietetic regimens quoted help deliver a child possessing good health, energy and strength. Besides this, Yoga is one unique technique (gentle movements and slow breathing methods) which is safe and effective during pregnancy. Hence an effort is made to understand systematic preventive measures of Ayurveda in pregnancy through this Pandemic. 
Keywords : Covid-19, Garbhasthapaka dravyas, Garbhini Paricharya, Pregnancy

\section{INTRODUCTION}

Pregnancy is the term used to describe the period in which a fetus develops inside a womens womb or uterus. Various physical and physiological changes during pregnancy are related to interplay between various hormones. ${ }^{1}$ This is principally a phenomenon of maternal adaption to the increasing demands of the growing fetus. ${ }^{2}$ Pregnancy in a small proportion of women can alter severe viral infections. Hence pregnant women placed in vulnerable category is caution. Some viral infections are worse in pregnant women, than other healthy adults if they develop covid -19 infection. Pregnant Women who are over weight, and those who have pre-existing medical problems such as high blood pressure and diabetes also appear to be at higher risk of developing severe illness. Regarding the aetiopathology of the physical \& systemic disorders that occur in the pregnant women it is same as in normal individual but principal of treatment differs as they can affect and harm the fetus. ${ }^{3}$ As the growth of the fetus solely depends upon the health and nutrition of the mother, Dietary regimen in pregnancy is one of the most essential aspect which should be taken care of to produce a positive healthy outcome.

\section{Systemic Regulations In Ayurveda}

Pregnant women with moderate or severe symptoms should be hospitalised mandatory for emergency care. Ayurvedic therapy should be considered only in pregnant women presenting with negative for COVID19 test. This includes the class of drugs beneficial for maintainance of pregnancy (Garbhasthapaka dravyas $)^{4}$ mentioned in classical text. There are also multifold drugs with Rasayana properties like Amalaki, Ashwagandha, Shatavari and Yastimadhu which helps enhance the immunity by increasing the health (Bala) and fight disease (Vyadi kshamatva). Pregnant women being more susceptible for infections like TORCH etc. results in abortions and repeated loss of pregnancy which may be prevented by these drugs.

Herbal Drugs During Pregnancy
Amalaki - Being a best Rasayana ${ }^{5}$ protects the body by subsiding the aggravated Doshas in addition to Antianaemic, Antioxidant and Antiviral pharmocological response ${ }^{6}$ considering this view, pregnancy is one such stage where the infections are commonly observed. Amalaki possessing the activity of Antiviral and Antioxidant properties best counteracts the harmful effect of Garbopaghatakara bhavas (harmful factors for the fetus) and helps in the appropriate maintanence of Garbha, prevents miscarriage and abortion. Hence the properties of Rasayana advance the immunity and prevent infections in fetus and frames right stability from the intra uterine period.

Part used : Fruit (The fruit can be consumed safely all round the year)

Dose: Powder 3 - 6gms

\section{Ashwagandha And Yastimadhu}

Both possess Antioxidant property. Antioxidants are important for prevention of Pre-eclampsia and Hypertensive disorder ${ }^{7,8}$. Also the oedema due to these condition is effectively prevented by Ashwangandha ${ }^{9}$ and Yastimadhu ${ }^{10}$ by it's Diuretic and Antiinflammatory properties. In addition, both are effective in reducing stress and anxiety ${ }^{9}$ possessing Antistress and Antidepressive activity ${ }^{11}$. As the fetus is completely dependant on the mother for it's growth and nutrition, due to the vitiated vata the fetus gets dried up and does not attain proper growth ${ }^{12}$ (IUGR) which is best estimated by the fetal size and fundal height ${ }^{13}$. As the two drugs aquiring the Vatahara along with Balya and Bruhmana properties help in good nourishment and growth of fetus.

Dose: Powder 3-6gms (The above drugs should be taken orally along with milk)

\section{Shatavari}

Premature contractions can be prevented by shatavari containing Antioxytocic effect ${ }^{14}$. Shatvarin $\mathrm{IV}$ is a glycoside of sarasasapogenin. The saponin in doses of 20-500 mcg / $\mathrm{ml}$ produces a special blockade of syntocinon (oxytocin) induced contractions of rat, 
guinea - pig and rabbit uteri in vitro and in situ. It also blocks the uterine spontaneous motility. Hence maintains trouble - free pregnancy throughout intrauterine life.
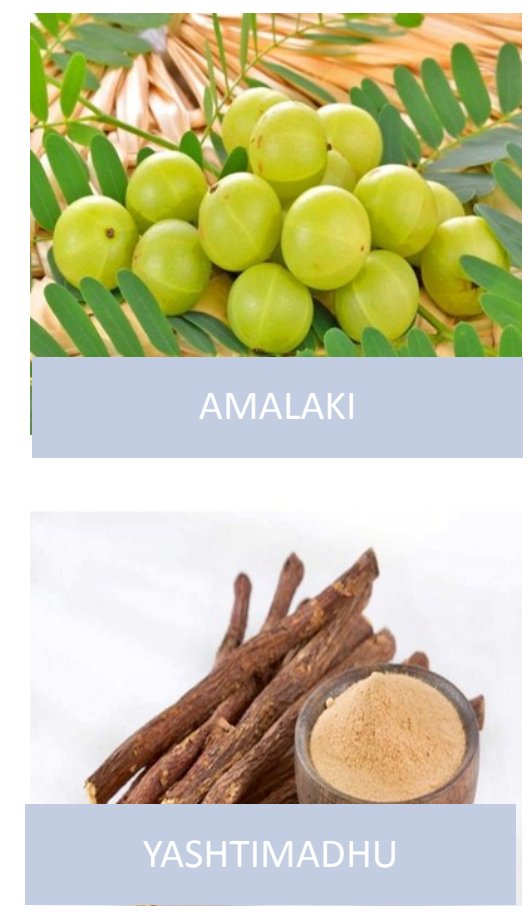

\section{GARBHINI WITH JWARA}

The combination of Raktachandana, Sariva, Lodhra \& Munakka (draksha) all taken in equal quantity, prepared Kwatha and added Sharkara as Prakshepa is best indicated in Garbhini Jwara ${ }^{16}$. Sariva being Tridoshahara, Jwaraghna \& Dahaprashamana is the best drug of choice possesing Kasaghna \& Swasahara properties ${ }^{17}$. Lodhra possessing Kapha Pittahara \& Jwaraghna properties used as a specific remedy for uterine complaints. ${ }^{18}$ The Ayurvedic Pharmacopia of India reccommends dried mature fruits in anemia, constipation, cough and dyspnoea. ${ }^{19}$ The above prescription can hence be recommended very safely in Garbhini Jwara which is good at nourishing, blood purifier and Antioxidant.

\section{Garbhini With Kasa \& Shwasa}

Yastimadhu(glycyrrhiza glabra) derives its flavours principally from a sweet tasting compound called Anethole. Additional sweetness in licorice comes from
Formulation : Shatavari grita ${ }^{15}$ indicated as best uterine tonic and Galactogogue.
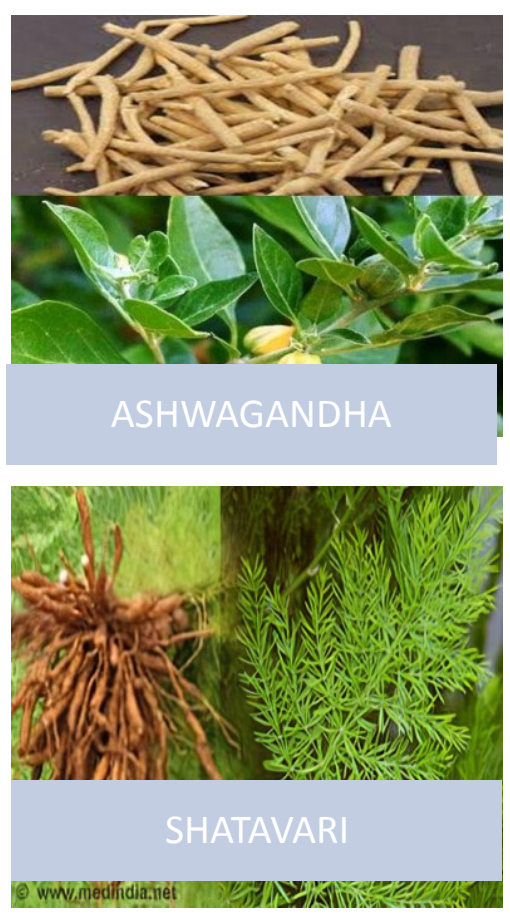

Glycyrrhizic acid, an Antiviral compound. Powdered licorice root is an effective expectorant. The roots of plants are used for throat and upper respiratory tract related infections \& contain many phenolic compounds such as flavanoids and their glycosides, coumarin \& cinnamic acid derivatives.

The active compound Triterpine saponins particularly Glycyrrhizic acid have shown Antiviral activity. Poly saccharide fractions obtained from glycyrrhiza glabra stimulate macrophages and hence elevate \& assist immune stimulation. Glycryrrhizic acid present in the plant inhibits virus growth \& inactivates virus particles ${ }^{20}$. Thus, Yastimadhu possessing Glycyrrhizic acid best counteracts the viral infections \& has been effectively used in throat \& upper respiratory tract infections. In addition to its Antioxidant properties it best nourishes the fetus and stimulates immune system throughout pregnancy. ${ }^{21}$

Formulation : Powder $3-6$ gms twice daily along with honey. 


\section{Garbhini Paricharya}

As said in classical text it is very much satisfactory and acceptable. The systems traditional action justifies excellent assitance for a confident and healthy outcome $^{22}$. Ayurveda follows the concept of Dinacharya which says that natural cycles are important for health. Hygiene, including regular bathing, oral hygiene, skin care $\&$ diet is also a central practice $^{23}$. Ayurveda has depicted various rules \& regimen (Ritucharya) regarding behaviour to acclimatize seasonal enforcement easily without altering body homeostasis. The prime principle of Ayurvedic system of medicine is preventive aspect which can be achieved by practices in response to change in climate condition. Lifestyle disorders being very common originating from lack of following seasonal regimen ${ }^{24}$.

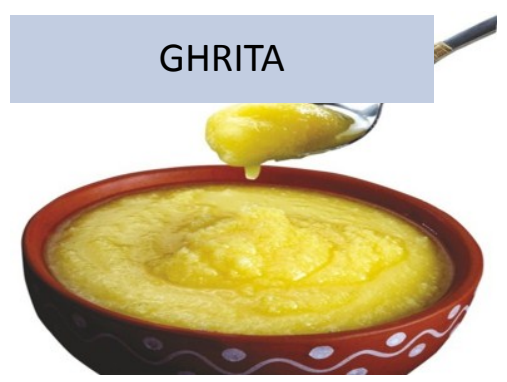

\section{Periodic Diet Administration \\ During First Trimester}

The reference on Madura, Sheeta, Drava Ahara indicated during the first three months checks dehydration, supplies appropriate nourishment, \& thereby maintains pregnancy ${ }^{25}$.

Milk is the best \& most complete of all foods. It is a fine blend of all the nutrients necessary for growth \& development. Milk is a good source of proteins, fats, sugars, vitamins \& minerals. It provides good bone health, good immune system, prevention of illness such as $-\mathrm{HTN}$, osteoporosis, dental decay \& respiratory problems.

\section{During Second Trimester}

The utility of Ghrita (Ghee), Navaneeta (Butter) \& Rice (Carbohydrates) during the next three months plays a major role in the maintainance of pregnancy. ${ }^{26}$
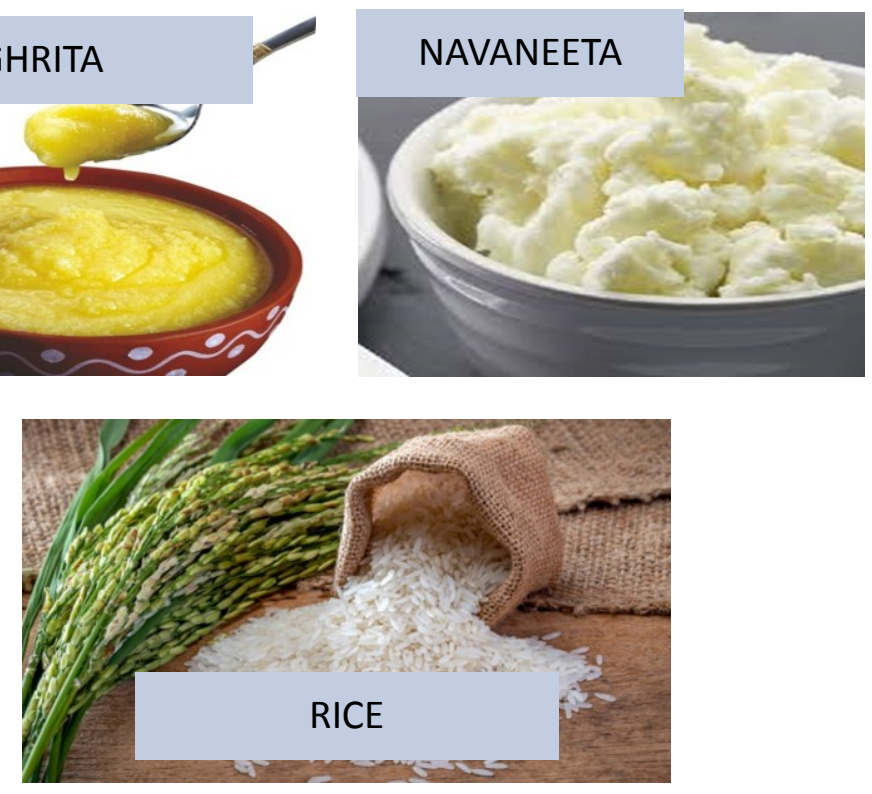

Ghrita - Promotes Smruti, Buddhi, Agni, Shukra, Oja, Kapha \& Meda. It is the richest source of milk fat. It is Rejuvinator, nutritive, protects bone marrow \& nerve tissue. It promotes fertility, immunity, vision, intelligence, liver function, enzyme function in intestine \& liver tissues. It is rich with Antioxidants \& acts as an aid in the absorption of vitamins \& mineral from other food.

Navaneeta - It has Anti- tumour \& Anti-cancer properties. It protects against tooth decay $\&$ builds the muscle. It contains fats, vitamins \& minerals. It is extremely rich in vitamin \& minerals which regulates cell growth \& protects fertility \& immune system. Folate ( called folic acid when in suppliment form ) helps prevent Neural tube defects, such as Spina bifida. Iodine is needed for Brain \& Nervous system development. Iron helps prevent anaemia in the mother, as well as low birth weight in the baby. 
Rice - Carbohydrates are important \& supply energy for the growing fetus. It provides the body \& brain with energy that enables them to work effectively.

\section{During Third Trimester}

The Maamsa rasa used in pregnancy, is rich in Proteins serves as the building blocks for the tremendous growth of the body tissues during pregnancy.

Enema - counters constipation and increase energy. Strengthens the pelvic floor \& thigh muscles. Due to the correct pathway of vayu the women delivers without difficulty \& remains free from complications.

\section{YOGA FOR PREGNANT WOMEN}

- Yoga provides holistic health benefits. ${ }^{27}$

- Yogasanas help keep the body supple. They relieve tension around the cervix by opening up the pelvic region. This prepares to be mothers for labour \& delivery.

- Yoga \& pranayama can train you to breath deeply $\&$ relax conciously.

- Helping you the demands of labor \& chidbirth.

- Yoga helps alleviate the effect of common symptoms such as morning sickness, painful leg cramps, swollen ankles \& constipation.

- Yogasanas also help pregnant women recover faster post- delivery.

Given here are a few simple exercises which will go a long way towards making you healthier \& fitter during pregnancy -

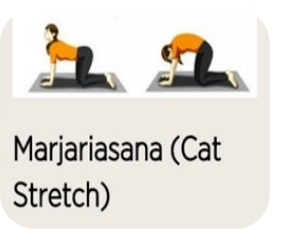

Stretch)
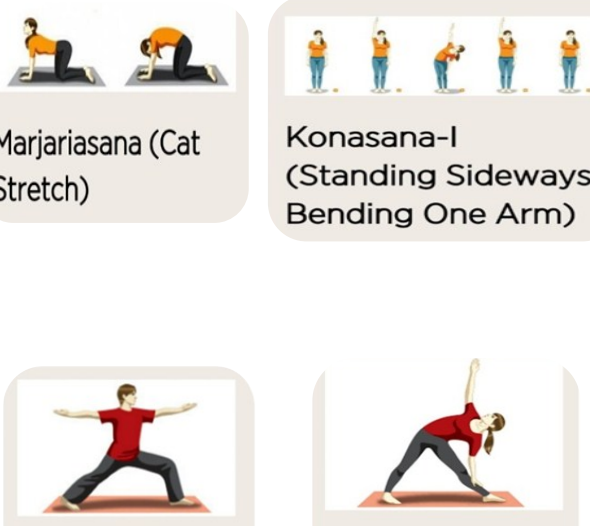

Veerbhadrasana (Warrior Pose)

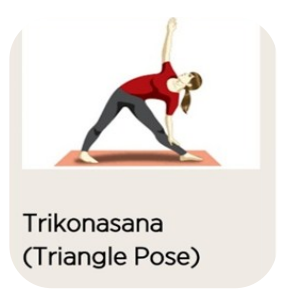

Badhakonasana (Butterfly Pose)
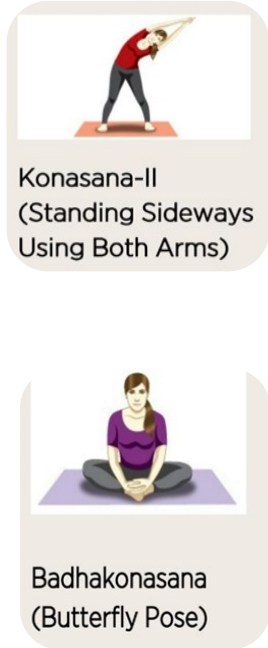
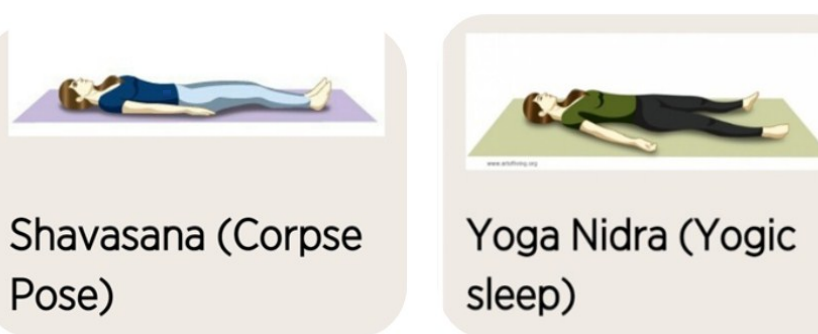


\section{Pranayama Or Breathing Exercises During} Pregnancy

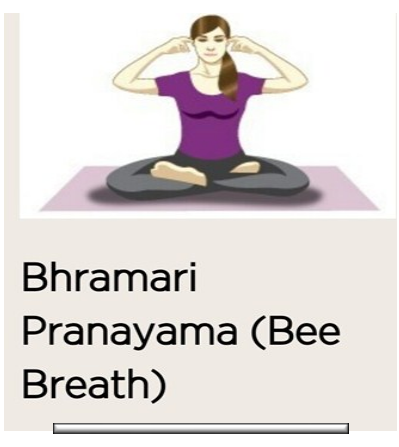

\section{Yoga Precautions For Pregnant Women}

- During the advanced stages of pregnancy, one should avoid yogasanas that put pressure on abdomen.

- For the first trimester of pregnancy, one should do standing yoga poses. This will help strengthen the legs \& enhance circulation. It can even reduce leg cramps.

- During the second \& third trimester, reduce the time spent holding asanas shown above to prevent fatigue. Hence, substitute with breathing exercises $\&$ meditation.

- Pregnant women should avoid practising yoga during $10^{\text {th }}$ to $14^{\text {th }}$ week of pregnancy since these are crucial times.

\section{Yoga Poses To Avoid During Pregnancy}

1. Naukasana (Boat Pose)

2. Chakrasana (Wheel Pose)

3. Ardha matsyendrasana (Sitting half spinal twist)

4. Bhujangasana (Cobra Pose)

5. Halasana (Plow Pose)

It is advisable to consult a doctor before taking up any yoga schedule during pregnacy. Learn $\&$ practice yoga postures under the supervision of a trained yoga teacher.

\section{Rasayana In Pregnant Women}

1. Phala grita ${ }^{28} 1$ tsp twice daily.

2. Kalyanaka grita ${ }^{29} 1$ tsp twice daily.

Pregnant women with pre-existing systemic disorders like Diabetes \& HTN, should sidestep the following
Pranayama releases negative emotions like anger \& irritability. They also help release stress, thus keeping the mind calm \& composed.

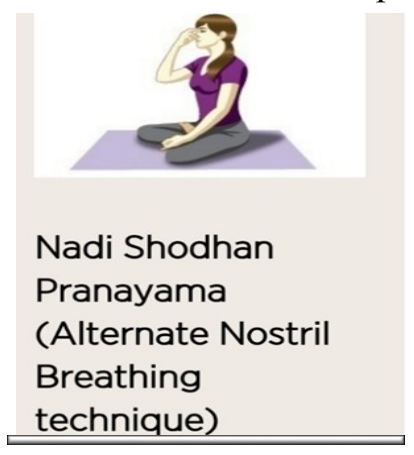

above mentioned treatment $\&$ should consult a doctor for further analysis \& cure.

\section{Sadvritta (Good Conduct \& Behaviour)}

Saumya manonukula katha shravana ${ }^{30}$ is well narrated in our science - for a woman who desires a perfect child. Pregnant woman should be entertained with talks which are gentle and pleasing to her mind. Listening actively to pleasant Mythological stories is more effective and acceptable which helps in enhancing the growth, development \& stabilizing the fetus. Suvadya ghosha, ${ }^{31}$ Playing soothing and melodious sounds of musical instruments in the surroundings helps keep the woman devoid of anxiety and stress.

\section{Music Therapy In Pregnancy}

Pregnancy is a wonderful time to prepare for your childs birth \& music can play an important role in shaping those months into something special. Pregnancy is a unique \& stressful period for many expectant mothers, they suffer anxiety and depression because of the long time period involved. Any intervention that reduces these problems is to be welcomed. Listening to suitable music provides a simple, cost-effective, non- invasive way of reducing stress, anxiety \& depression during pregnancy ${ }^{32}$.

Best during $-2^{\text {nd }} \& 3^{\text {rd }}$ trimester

Choice of music - Nature sounds or Lullabies

\section{Benefits}

- Music reduces pregnancy stress levels. 
- Music helps strengthen the bond with your unborn child. ${ }^{33}$

\section{DISCUSSION}

In this global crisis, COVID-19 the pre-emptive regulations \& its importance is wellexplained in our science. In this view the state of pregnancy being vulnerable for infections additional care and attention to be taken.Certain traditional herbal medicines with natural compounds like Anti-oxidant, Immunomodulators, Antiviral and Anti-inflammatory properties etc reduces the risk of infections(viral, bacterial and TORCH ), complications \& thereby helps maintain healthy pregnancy throughout.Further, Garbhini Paricharya (Systemic Regimens) plays an essential \& safe antenatal care which recommends Ahara, Vihara to assist develop the fetus without anomalies, benefits to nourish and support fullterm normal delivery. Accompanying with Yoga and breathing techniques during pregnancy increases oxygen supply towards the fetus, reduces anxiety, helps promote sound sleep and capacity to withstand labour pain in mother. Music therapy also connects women to the fetus inside and allows to discover a new bondage \& strength within.

\section{CONCLUSION}

Ayurveda being the science of life, promulgates the gifts of nature in maintaining healthy and happy living. Ayurveda's comprehensive knowledge based on preventive care, derives from the perception of 'Dinacharya'- Daily regimes and 'Ritucharya' Seasonal regimes to maintain wellness of life. The simplicity of awareness about oneself and the harmony each individual can achieve by uplifting $\&$ maintaining his or her immunity is emphasized across the traditional literature. Classical scriptures provides a number of preventive and curative measures for ensuring the safety and good health of both mother and fetus, thereby avoiding the complications during pregnancy like Stillbirth, Abortion, Preterm delivery, PPH, etc. Following the selfcare guidelines (Ahara, Vihara, Aushadha \& Sadvritta) for preventive health measures and boosting immunity in this crisis of Covid-19 helps the mankind to re-establish Physical, Psychological and Social wellbeing.

\section{REFERENCES}

1. Richa saxena, obstetrics \& gynecology, first edition, Jaypee brothers medical publishers (P) LTD . Newdelhi page no -3 .

2. D C Dutta, Text book of obstetrics, edited by Hiralal konar, $9^{\text {th }}$ edition , Jaypee brothers medical publishers (P) LTD .Newdelhi page no -42.

3. Prof. Premavati tiwari, Kashyapa samhita vruddha jeevakeeya tantra , khilasthana $-10^{\text {th }}$ chapter , 2018 reprint edition, chaukambha vishvabharati varanasi page no -553 .

4. Agnivesha, Charaka samhita,Sri.Satyanarayana shastry by Pt.Kashinath shastri.Dr.Gorakha nath chaurvedi part1 Chaukamba Bharathi Academy Varanasi reprint:1998 Sharirasthana Chapter 4 Shloka no.20 page no- 927

5. Bhavaprakasha nigantu commentary by Dr.K.C.Chunekar. Chaukamba Bharati Academy Haritakyadi varga Sholka no. 39 page no. 10

6. C.P.Khare (Ed.) Indian medicinal plants new Delhi. India ISBN:978-0-387-70637-5 Springer - Verlag Berlin /Hiedelberg .P.No.246/836

7. Gupta SK, Dua A, Vohra BP .,Withania somnifera (ASHWAGHANDHA) attenuates antioxidant defence in shed spinal cord inhabits copper included lipid peroxidation and protein oxidative modifications, drug metabolism and drug interaction, 2003;19:211-222

8. Bhattacharya A,GhosalS, Bhattachrya SK, antioxidant activity of teennoid principals of emblica offinalis (amla) in chronic stress include changes in rat brain . Indian journal of experimental biology, 2000;38:877880

9. C.P.Khare (Ed.) Indian medicinal plants new Delhi. India ISBN:978-0-387-70637-5 Springer - Verlag Berlin /Hiedelberg .P.No.716/836

10. Dravyaguna vijnana by Dr Prakash L Hegde, Dr Harini A , Chaukamba publications new Delhi edition first, 2014.P.No 906

11. C.P.Khare (Ed.) Indian medicinal plants new Delhi. India ISBN:978-0-387-70637-5 Springer - Verlag Berlin /Hiedelberg .P.No.295,296/836

12. Sushruta Samhita ,edition by vaidya yadavji Trikamji Axharya ,Sareera sthana ,Chowkamba . Sanskrit samsthan, Varanasi reprint 2013, chapter 10 ,shloka no: 57 
13. DC Duttas text book of obstridicts edited by Hiralal konar ,enlarged and re-vised reprint of eighth edition ,2015,chapter32 ,page no 533 pp 782

14. Astanga hridaya ,vagbharatha , Krishna ramachandra shastri Narvare by Bisagacharya Harisastri paradakara vaidya Chaukamba orientalia Varanasi ,9th edition 2002, uttarasthana, shloka no 156 pg no 937

15. Vd. Harish chandra singh kuswaha, Acharya V. J. Thakar,Charak samhita shareera sthana (Ayurveda Dipika's Ayushi Hindi - commentary) chaukamba orientalia edition $20168^{\text {th }}$ chapter page no -867 .

16. Yogaratnakara, by vaidya lakshmipati sastri by bhisaratna Brahmankar sastri choukamba prakashan varanasi edition : Reprinted ,2013 shloka no :2 pg no. 420

17. Bhavaprakasha nigantu commentary by $\mathrm{Dr} \mathrm{K} C$ Chunekar chaukamba Bharati acadamym Guduchyadi varga pgno : 426

18. Bhavaprakasha nigantu commentary by $\mathrm{Dr} \mathrm{K} \mathrm{C}$ Chunekar chaukamba Bharati acadamy, Haritakyadidravya pg no : 128

19. C.P.Khare (Ed.) Indian medicinal plants new Delhi. India ISBN:978-0-387-70637-5 Springer - Verlag Berlin /Hiedelberg .P.No.636 / 836

20. C.P.Khare (Ed.) Indian medicinal plants new Delhi. India ISBN:978-0-387-70637-5 Springer - Verlag Berlin /Hiedelberg .P.No.711/836

21. Rajesh Arora, $\mathrm{R}$ chawla et al, Potential of complementary and alternative medicine in preventive management of Novel HN Flu (swine Flu ) pandemic, Thwarting potential disasters in the Bud. Review article / vol.2011 / Aticle I D 586506 / 16 pages

22. Dr. Anna Moreswar Kunte \& Ramchandra Sastri Navre, Astangha, Hrudaya of Vagbhata Arunadutta \& Hemadri commentary . sutrasthana $2^{\text {nd }}$ chapter edited by Pt. Hari sadasivasastri Paradakara 2016 reprint edition, chaukambha sanskrit sansthan, Varanasi page no - 24 .

23. Dr. Anna Moreswar Kunte \& Ramchandra Sastri Navre , Astangha Hrudaya of Vagbhata Arunadutta \& Hemadri commentary. sutrasthana $3^{\text {rd }}$ chapter edited by Pt. Hari sadasivasastri Paradakara 2016 reprint edition, chaukambha sanskrit sansthan, Varanasi page no - 37 .

24. Prof. Jyoti Mitra Astangha sangraha of vrudda vaghbhata, Indu commentary shareera sthana $3^{\text {rd }}$ chapter edited by Dr. Shivaprasad sharma choukamba sanskrit series office, Varanasi page no -285 .

25. Vaidya. V.T. Acharya Ram Acharya Kavyatirtha Susrutha Samhita by Susrutha Dalhana commentary shareera sthana $10^{\text {th }}$ chapter 2017 reprint edition, chaukambha sanskrit sansthan, Varanasi page no -387 .

26. Prof. Dr. V.N.K. Usha Prasuti tantra (Text book of obstetrics) vol.1 chaukambha sanskrit pratishtan first edition $20123^{\text {rd }}$ chapter page no-374.

27. Art of living, Yoga: A Godsend for pregnant woman, 2021, http://www.artofliving.org/in-en/yoga/yoga-forwomen/yoga-and-pregnancy.

28. Astanga hridaya ,vagbharatha, Krishna ramachandra shastri Narvare by Bisagacharya Harisastri paradakara vaidya Chaukamba orientalia Varanasi ,9th edition 2002,uttarasthana ,chapter -34 shloka 63-67 page no 901

29. Astanga hridaya ,Vagbhata , Krishna ramachandra shastri Narvare by Bisagacharya Harisastri paradakara vaidya Chaukamba orientalia Varanasi ,9th edition 2002,uttarasthana ,chapter -6 shloka 26-31 page no 799.

30. Agnivesha,charaka samhita, Edited and Revised by Kaviraj shree narendranath sengupta and kaviraja shree balaichandra sengupta, Chaukamba Publishers Varanasi reprint: $2^{\text {nd }}$ edition, 2002, Sharirasthana Chapter $8 / 20$ page no- 2062

31. Vrddha Jeevaka, Kasyapa Samhita, With Vidyotini Hindi commentary by Sri Satyapala Bhisagacharya, Chaukhamba sanskrit sansthaan, Varanasi, Edition: Reprint 2010, chapter 5/ 12, page no. 84

32. Wilbert, C. (2008, October 08). Music reduces pregnancy stress. Retrieved February 18, 2021, from https://www.webmd.com/baby/news/20081008/musicreduces-pregnancy-stress

33. Wong, C., (2020, September 17). The Benefits of Music Therapy. Retrieved from https://www.verywellmind.com/benefits-of-music-therapy- 89829

\section{Source of Support: Nil Conflict of Interest: None Declared}

How to cite this URL: Nikitha Sirigere et al:Pre-Emptive Regulations Of Covid-19 During Pregnancy - An Ayurvedic View. International Ayurvedic Medical Journal \{online\} 2021 \{cited March, 2021\} Available from: http://www.iamj.in/posts/images/upload/625 632.pdf 